\title{
Impact of Nitrogen and Silicon on Growth Parameters and Nutrient Uptake of Transplanted Rice (Oryza sativa $\mathrm{L}$.) under Temperate Conditions
}

\author{
Rukhsana Jan ${ }^{1 *}$, Farooq Ahmad Aga ${ }^{1}$, Monica Reshi ${ }^{2}$ and Khalid Ul Islam Rather ${ }^{3}$ \\ ${ }^{1}$ Division of agronomy, Sher-e- Kashmir University of Agricultural Sciences and Technology \\ of Kashmir, Shalimar Srinagar 190025, India \\ ${ }^{2}$ Division of Post-Harvest Technology, Sher-e-Kashmir University of Agricultural Sciences \\ and Technology of Kashmir, Shalimar Srinagar 190025, India \\ ${ }^{3}$ Division of Statistics and Computer Science, Main Campus Sher-e-Kashmir University of \\ Agricultural Sciences and Technology of Jammu, Chatha Jammu-180009, India \\ *Corresponding author
}

\begin{tabular}{|c|c|}
\hline & A B S T R A C T \\
\hline & The field experiment was conducted at Agronomy Research Farm of SKUAST-K \\
\hline Keywords & $\begin{array}{l}\text { during Kharif season } 2014 \text { and } 2015 \text {. Three } \mathrm{N} \text { levels }\left(\mathrm{N}_{1}: 120, \mathrm{~N}_{2}: 150, \mathrm{~N}_{3}: 180\right. \\
\mathrm{kg} / \mathrm{ha} \text { ) and four } \mathrm{Si} \text { applications }\left(\mathrm{Si}_{0}: \text { Control, } \mathrm{Si}_{1}: 5 \%, \mathrm{Si}_{2}: 10 \% \text { and } \mathrm{Si}_{3}: 15 \%\right) \text { were }\end{array}$ \\
\hline $\begin{array}{l}\text { Growth, Nitrogen, } \\
\text { Rice, Silicon, } \\
\text { Uptake and yield }\end{array}$ & $\begin{array}{l}\text { applied to the rice crop. Number of tillers } \mathrm{m}^{-2} \text { and relative growth rate were } \\
\text { significantly highest with } 180 \mathrm{kgN} \mathrm{ha}^{-1} \text { from } 30-45 \mathrm{DAT} \text { but from } 60 \mathrm{DAT} \text { upto } \\
\text { harvest, these growth parameters were significantly highest with } 120 \mathrm{kgN} \mathrm{ha}^{-1} \text {. }\end{array}$ \\
\hline Article Info & However, number of tillers $\mathrm{m}^{-2}$ and relative growth rate were significantly highest \\
\hline $\begin{array}{l}\text { Accepted: } \\
18 \text { March } 2020 \\
\text { Available Online: } \\
10 \text { April } 2020\end{array}$ & $\begin{array}{l}\text { with } 15 \% \mathrm{Si} \text {. Nitrogen as well as silicon applications could not make any } \\
\text { significant difference on their respective content of grain and straw. } 120 \mathrm{kgN}^{-1} \\
\text { and } 15 \% \mathrm{Si} \text { resulted in significantly highest nitrogen and silicon uptake by crop, } \\
\text { respectively. The treatment combination with } 120 \mathrm{kgN} \mathrm{ha}^{-1} \text { and } 15 \% \mathrm{Si} \text { proved to } \\
\text { be the best as it produced highest grain vield during both the vears. }\end{array}$ \\
\hline
\end{tabular}

\section{Introduction}

Rice (Oryza sativa L.) belonging to family Graminae and sub family Poacea is a staple food for more than half of the world's population. Globally it is grown on an acreage of 158 million hectares with total production of 700 million tonnes and productivity 4.43 ton per hectare (FAO, 2014). In India, it is grown on an area of about 43.4 million hectare with the production of 157.2 million tonnes and productivity of 3.6 tonnes per hectare (FAO, 2014).

In Jammu and Kashmir rice is grown on an area of 261.66 hectares with a production of 5456 quintals and productivity of 20.95 quintals per hectares (DES, 2012-2013). 
Application of nitrogen fertilizer is an important practice for increasing rice yield. It is essential to the rice plant, with about 75 per cent of leaf nitrogen associated with chloroplasts, which are physiologically important in dry matter production (Dalling, 1995). Rice plants require nitrogen during the vegetative phase to promote and tillering, which determines the potential number of panicles (Mae, 1997). The presence of nitrogen in excess promotes development of the above ground organs with abundant dark green (high chlorophyll) tissues of soft consistency and relatively poor root growth. Silicon is usually considered as one of the most important beneficial an element for rice production as rice requires large amounts of silica for its growth. It is estimated that nearly $20 \mathrm{~kg}$ of silica is removed from the soil by rice plants for production of $100 \mathrm{~kg}$ brown rice (Dobermann and Fairhurst, 1997).

Silicon helps plants to overcome multiple stresses including biotic stresses such as insect-pests and diseases like blast, brown spot and sheath blight and also abiotic stresses such as metal toxicity, salinity, drought and temperature (Ma, 2004 and Liang et al., 2007). Rice is considered to be a silicon accumulator plant and tends to actively accumulate $\mathrm{Si}$ to tissue concentrations of $5 \%$ or higher. Keeping in view the above facts, the present study was designed to study the impact of nitrogen and silicon on growth and to study the interaction effect of nitrogen and silicon on grain yield. To the best of our knowledge, it is the first study regarding the effect of silicon on growth and grain yield of transplanted rice in Kashmir.

\section{Materials and Methods}

The field experiment was carried out at Research Farm of Sher-e-Kashmir University of Agricultural Sciences and Technology of Kashmir, Shalimar during Kharif season, 2014 and 2015. The soil of the experiment was silty clay loam in texture, neutral in reaction with medium available nitrogen, phosphorus, potassium and low available silicon. The two factorial experiments were based on completely randomised block design with four replications. The factors included three $\mathrm{N}$ levels $\left(\mathrm{N}_{1}: 120, \mathrm{~N}_{2}: 150, \mathrm{~N}_{3}: 180\right.$ $\mathrm{kg} / \mathrm{ha}$ ) and four $\mathrm{Si}$ applications $\left(\mathrm{Si}_{0}\right.$ : Control, $\mathrm{Si}_{1}: 5 \%, \mathrm{Si}_{2}: 10 \%$ and $\mathrm{Si}_{3}: 15 \%$ ) and the treatment combinations were $\mathrm{N}_{1} \mathrm{Si}_{0}, \mathrm{~N}_{1} \mathrm{Si}_{1}$, $\mathrm{N}_{1} \mathrm{Si}_{2}, \quad \mathrm{~N}_{1} \mathrm{Si}_{3}, \quad \mathrm{~N}_{2} \mathrm{Si}_{0}, \quad \mathrm{~N}_{2} \mathrm{Si}_{1}, \quad \mathrm{~N}_{2} \mathrm{Si}_{2}, \quad \mathrm{~N}_{2} \mathrm{Si}_{3}$, $\mathrm{N}_{3} \mathrm{Si}_{0}, \mathrm{~N}_{3} \mathrm{Si}_{1}, \mathrm{~N}_{3} \mathrm{Si}_{2}$ and $\mathrm{N}_{3} \mathrm{Si}_{3}$.

Number of tillers was counted at 15 days interval after transplanting till harvest from one metre marked row of each plot and expressed as tillers $\mathrm{m}^{-2}$.

Relative growth rate was recorded at 15 days interval after transplanting till harvest using the formula,

$\mathrm{RGR}=$ Loge $\mathrm{W}_{2}-\mathrm{LogeW}_{1} / \mathrm{t}_{2}-\mathrm{t}_{1}$

Where $\mathrm{W}_{1}$ and $\mathrm{W}_{2}$ are dry matter at times $\mathrm{t}_{1}$ and $t_{2}$ respectively

\section{Grain yield}

After two days of sun drying of bundles, each net plot was separately threshed. Grain yield of each plot was recorded separately as $\mathrm{kg}$ plot $^{-1}$ and then converted into $\mathrm{q} \mathrm{ha}^{-1}$ Nitrogen content was estimated by modified Kjeldhal method (Jackson, 1973) after digesting 0.5g of plant sample (grain and straw) with $10 \mathrm{ml}$ concentrated sulphuric acid and digestion mixture, content was expressed in per cent. Silicon content was estimated by vanadomolybdo phosphoric yellow method using spectrophotometer after digestion of the samples and expressed in per cent. Nitrogen and silicon uptake was calculated by multiplying grain and straw yield with respective percentages of nitrogen and silicon content and expressed in $\mathrm{kgha}^{-1}$. 


\section{Results and Discussion}

\section{Tiller count}

Different nitrogen levels induce significant variation in tillers $\mathrm{m}^{-2}$ (Fig. 1). Tiller number increased rapidly from 15DAT to 45DAT, thereafter decreased gradually upto harvest with respect to both factors viz. nitrogen levels and silicon applications during both the years. Significantly highest numbers of tillers $\mathrm{m}-2$ from 30DAT upto 45DAT were recorded with $180 \mathrm{kgN} \mathrm{ha}^{-1}$. This could be attributed to the fact that higher dose of nitrogen being constituent of enzymes and protein enhanced cell expansion and various metabolic processes. Similar findings reported by Lawlor (2002) and Arnold et al., (2006). From 60DAT upto harvest, significantly highest numbers of tillers $\mathrm{m}-2$ were recorded with $120 \mathrm{kgN} \mathrm{ha}^{-1}$ during both years. It is because of reduction of tiller number per plant at later growth stages might be due to tiller mortality and competition was more for growth resources. These results are in agreement with those obtained by Mesquita and Pinto (2000) and Pathan et al., (2010). Among silicon applications, significantly highest tiller counts from 45DAT upto harvest were recorded with $15 \% \mathrm{Si}$ during both years. It might be due to silicon helps in increase the erectness of leaves, reduces leaf shading, increases light interception thereby increasing photosynthetic capacity which may result in increased tiller number. Fallah (2000) concluded, by increasing the amount of silicon in nutrient solution feeding, the tillering of rice has increased.

\section{Relative growth rate}

The relative growth rate was significantly affected by different nitrogen and silicon applications (Fig. 2). From 30DAT up to 45DAT, relative growth rate were significantly highest with $180 \mathrm{kgN} \mathrm{ha}^{-1}$ during both the years. It might be due to the reason that higher dry weight was obtained with this treatment only. However, from 60DAT up to harvest, relative growth rate was significantly highest with $120 \mathrm{kgN} \mathrm{ha}^{-1}$ during both the years. Among silicon applications, $15 \% \mathrm{Si}$ resulted in significantly higher relative growth rate during both the years. It is because the silicon nutrition increases the antioxidant production and reduces the generation of reactive oxygen species which in turn reduces the photo oxidative damage and maintains the integrity of chloroplast membrane which caused more dry weight results in higher relative growth rate.

\section{Interaction effect on grain yield}

The interaction effect between nitrogen levels and silicon applications was significant (Table 1 and 2). Lowest grain yield was achieved in treatment combination $\mathrm{N}_{3} \mathrm{Si}_{0}\left(180 \mathrm{kgN}\right.$ ha ${ }^{-1}$ and no $\mathrm{Si}$ ) and was estimated to be 64.17 $\mathrm{q} \mathrm{ha}^{-1}$ and 64.83q ha ${ }^{-1}$ during 2014 and 2015, respectively. Significantly higher grain yield $\left(80.05 \mathrm{q} \mathrm{ha}^{-1}\right.$ and 80.62q ha $\left.{ }^{-1}\right)$ was recorded in treatment combination $120 \mathrm{kgN} \mathrm{ha}{ }^{-1}$ and $15 \% \mathrm{Si}$ but remained at par with $150 \mathrm{kgN} \mathrm{ha}^{-1}$ and $15 \% \mathrm{Si}\left(78.76 \mathrm{q} \mathrm{ha}^{-1}\right.$ and $\left.79.53 \mathrm{q} \mathrm{ha}^{-1}\right)$ during 2014 and 2015. It might be due to the reason that decreases in nitrogen dose and increase in $\mathrm{Si}$ application, number of blank spikelets per panicle was decreased, hence increased grain yield. These results are in close confirmity with Rajamani et al., (2013).

\section{Nitrogen and silicon content}

Thet nitrogen levels and silicon applications could not make any significant difference in nutrient content of grain and straw during both the years (Table 3). It is attributed to the fact that uptake of nutrients is accompanied by increase in growth (biomass production) of plant. Thus, increased absorption of nutrients well buffered by increased dry matter production failed to show any significant change in nutrient content of grain and straw. 
This is in agreement with the findings of Alfoldi et al., (1994).

\section{Nitrogen and silicon uptake}

Nitrogen and silicon uptake was significantly affected by their respective applications (Table 4). $120 \mathrm{kgN} \mathrm{ha}^{-1}$ recorded significantly highest nitrogen uptake of grain $(81.55 \mathrm{kgN}$ $\mathrm{ha}^{-1}$ and $82.55 \mathrm{kgN} \mathrm{ha}^{-1}$ ) and straw $(44.77 \mathrm{~kg}$ $\mathrm{ha}^{-1}$ and $45.52 \mathrm{~kg} \mathrm{ha}^{-1}$ ) during 2014 and 2015 . This may be associated with maximum grain and straw yield. Fageria et al., (2003); Fageria et al., (2009) and Shinano et al., (1995) obtained the same results.

Data further revealed that among different silicon applications, $15 \% \mathrm{Si}$ recorded significantly highest silicon uptake of grain $\left(82.46 \mathrm{~kg} \mathrm{ha}^{-1}\right.$ and $\left.83.40 \mathrm{~kg} \mathrm{ha}^{-1}\right)$ and straw uptake (45.22 $\mathrm{kg} \mathrm{ha}^{-1}$ and $\left.45.75 \mathrm{~kg} \mathrm{ha}^{-1}\right)$ during both the years. This might be due to increase in root and shoot growth and enhanced silicon availability with higher rate of silicon application. These findings are in agreement with the reports of Singh et al., (2006).

The two year study revealed that silicon applications can significantly regulate plant growth, and yield if applied at proper time with optimum concentration. As far as fertilization of rice crop is concernedapplication of nitrogen fertilizer is an important practice for increasing rice yield.

Fig.1 Impact of nitrogen and silicon on tiller count $\left(\mathrm{m}^{-2}\right)$ of transplanted rice
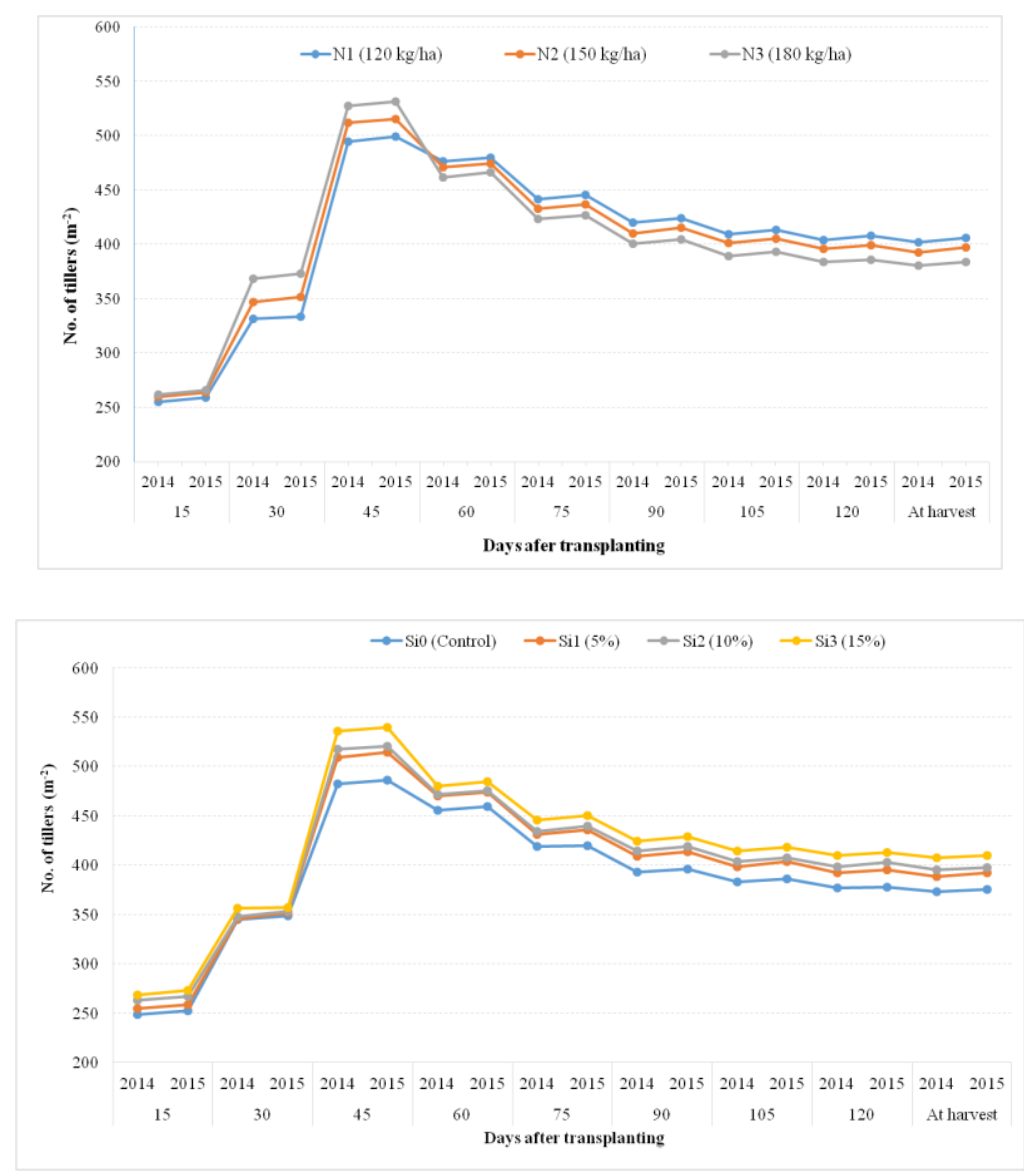
Table.1 Interaction of nitrogen and silicon on grain yield of transplanted rice of year 2014

\begin{tabular}{|l|l|l|l|l|}
\hline \multirow{2}{*}{ Treatments } & \multicolumn{4}{|c|}{ Year $\mathbf{2 0 1 4}$} \\
\hline Nitrogen levels $\left(\mathbf{k g ~ h a}^{-\mathbf{1}}\right)$ & Control $\left(\mathbf{S i}_{\mathbf{0}}\right)$ & $\mathbf{5}\left(\mathbf{S i}_{\mathbf{1}}\right)$ & $\mathbf{1 0}\left(\mathbf{S i}_{\mathbf{2}}\right)$ & $\mathbf{1 5}\left(\mathbf{S i}_{\mathbf{3}}\right)$ \\
\hline $\mathbf{1 2 0}\left(\mathbf{N}_{\mathbf{1}}\right)$ & 70.15 & 75.23 & 76.89 & 80.05 \\
\hline $\mathbf{1 5 0}\left(\mathbf{N}_{\mathbf{2}}\right)$ & 66.17 & 73.95 & 75.33 & 78.76 \\
\hline $\mathbf{1 8 0}\left(\mathbf{N}_{\mathbf{3}}\right)$ & 64.17 & 69.08 & 70.28 & 70.42 \\
\hline $\mathbf{S E m}$ & \multicolumn{4}{|c|}{$\mathbf{0 . 6 1}$} \\
\hline $\mathbf{C D}(\mathbf{P} \leq \mathbf{0 . 0 5})$ & \multicolumn{5}{|c|}{$\mathbf{1 . 8 5}$} \\
\hline
\end{tabular}

Table.2 Interaction of nitrogen and silicon on grain yield of transplanted rice of year 2015

\begin{tabular}{|l|c|c|c|c|}
\hline \multirow{2}{*}{ Treatments } & \multicolumn{4}{|c|}{ Year $\mathbf{2 0 1 5}$} \\
\hline Nitrogen levels $\left(\mathbf{k g ~ h a}^{-\mathbf{1}}\right)$ & Control $\left(\mathbf{S i}_{\mathbf{0}}\right)$ & $\mathbf{5}\left(\mathbf{S i}_{\mathbf{1}}\right)$ & $\left.\mathbf{1 0} \mathbf{( S i}_{\mathbf{2}}\right)$ & $\mathbf{1 5}\left(\mathbf{S i}_{\mathbf{3}}\right)$ \\
\hline $\mathbf{1 2 0}\left(\mathbf{N}_{\mathbf{1}}\right)$ & 71.01 & 76.19 & 77.72 & 80.62 \\
\hline $\mathbf{1 5 0}\left(\mathbf{N}_{\mathbf{2}}\right)$ & 67.13 & 75.01 & 76.39 & 79.53 \\
\hline $\mathbf{1 8 0}\left(\mathbf{N}_{\mathbf{3}}\right)$ & 64.83 & 69.81 & 71.04 & 71.18 \\
\hline $\mathbf{S E m} \pm$ & \multicolumn{4}{|c|}{} \\
\hline $\mathbf{C D}(\mathbf{P} \leq \mathbf{0 . 0 5})$ & $\mathbf{0 . 6 7}$ \\
\hline
\end{tabular}

Fig.2 Impact of nitrogen and silicon on relative growth rate $\left(\mathrm{g} \mathrm{g}^{-1}\right.$ day $\left.{ }^{-1}\right)$ of transplanted rice
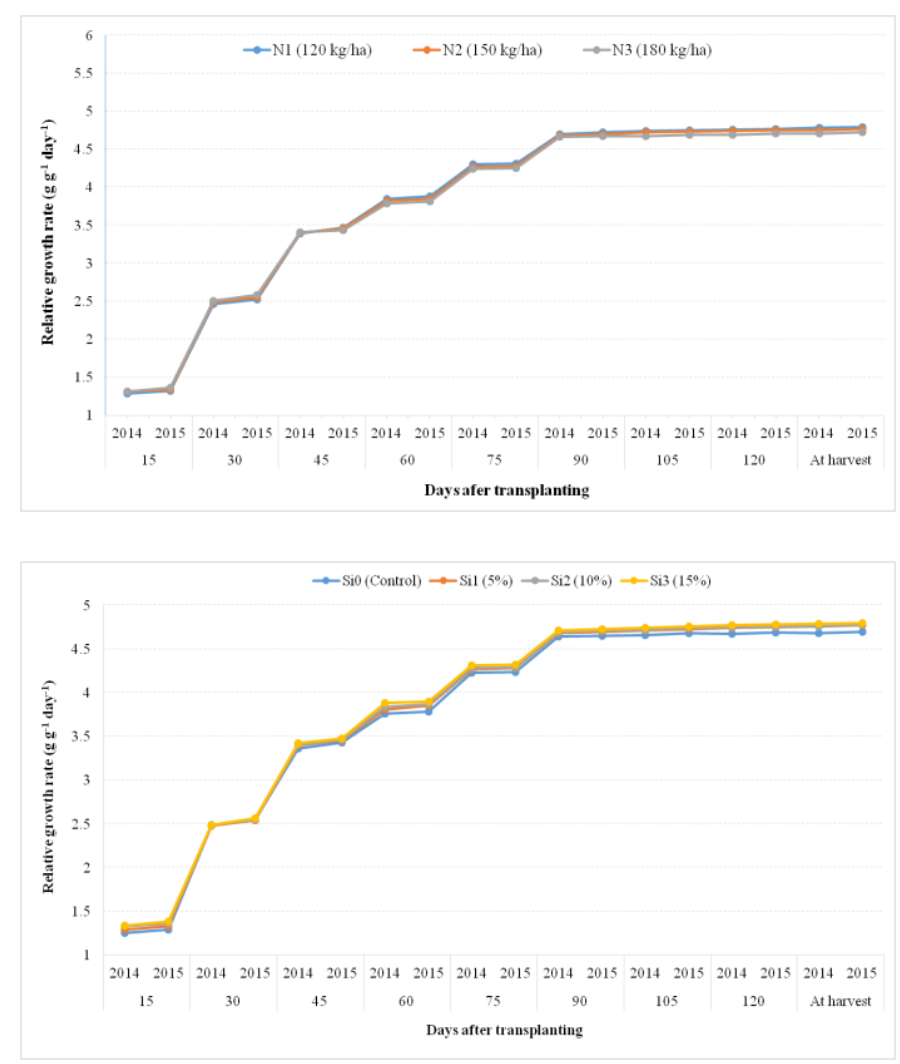
Table.3 Impact of nitrogen and silicon on nitrogen and silicon content of transplanted rice

\begin{tabular}{|c|c|c|c|c|c|c|c|c|}
\hline \multirow{3}{*}{$\begin{array}{l}\text { Years } \\
\text { Treatments }\end{array}$} & 2014 & 2015 & 2014 & 2015 & 2014 & 2015 & 2014 & 2015 \\
\hline & \multicolumn{4}{|c|}{ Nitrogen content $(\%)$} & \multicolumn{4}{|c|}{ Silicon content $(\%)$} \\
\hline & \multicolumn{2}{|c|}{ Grain } & \multicolumn{2}{|c|}{ Straw } & \multicolumn{2}{|c|}{ Grain } & \multicolumn{2}{|c|}{ Straw } \\
\hline \multicolumn{9}{|c|}{ Nitrogen levels $\left(\mathrm{kg} \mathrm{ha}^{-1}\right)$} \\
\hline $120\left(\mathrm{~N}_{1}\right)$ & 1.078 & 1.080 & 0.478 & 0.480 & 2.58 & 2.59 & 3.69 & 3.70 \\
\hline $150\left(\mathrm{~N}_{2}\right)$ & 1.077 & 1.079 & 0.477 & 0.479 & 2.56 & 2.58 & 3.67 & 3.68 \\
\hline $180\left(\mathbf{N}_{3}\right)$ & 1.075 & 1.078 & 0.475 & 0.477 & 2.52 & 2.56 & 3.65 & 3.68 \\
\hline SEm \pm & 0.0009 & 0.003 & 0.0008 & 0.0009 & 0.01 & 0.02 & 0.01 & 0.02 \\
\hline $\mathrm{CD}(\mathrm{p} \leq 0.05)$ & NS & NS & NS & NS & NS & NS & NS & NS \\
\hline \multicolumn{9}{|c|}{ Silicon applications (\%) } \\
\hline Control $\left(\mathbf{S i}_{0}\right)$ & 1.075 & 1.077 & 0.475 & 0.477 & 2.53 & 2.54 & 3.63 & 3.66 \\
\hline $5 \quad\left(\mathbf{S i}_{1}\right)$ & 1.075 & 1.079 & 0.477 & 0.479 & 2.54 & 2.57 & 3.66 & 3.68 \\
\hline $10\left(\mathbf{S i}_{2}\right)$ & 1.078 & 1.080 & 0.477 & 0.479 & 2.55 & 2.59 & 3.68 & 3.70 \\
\hline $15\left(\mathbf{S i}_{3}\right)$ & 1.079 & 1.081 & 0.478 & 0.480 & 2.59 & 2.63 & 3.69 & 3.72 \\
\hline SEm \pm & 0.001 & 0.003 & 0.001 & 0.001 & 0.01 & 0.03 & 0.02 & 0.02 \\
\hline $\mathrm{CD}(\mathrm{p} \leq 0.05)$ & NS & NS & NS & NS & NS & NS & NS & NS \\
\hline
\end{tabular}

Table.4 Impact of nitrogen and silicon on nitrogen and silicon uptake of transplanted rice

\begin{tabular}{|c|c|c|c|c|c|c|c|c|}
\hline \multirow{3}{*}{$\begin{array}{l}\text { Years } \\
\text { Treatments }\end{array}$} & 2014 & 2015 & 2014 & 2015 & 2014 & 2015 & 2014 & 2015 \\
\hline & \multicolumn{4}{|c|}{ Nitrogen uptake $\left(\mathrm{kg} \mathrm{ha}^{-1}\right)$} & \multicolumn{4}{|c|}{ Silicon uptake $\left(\mathrm{kg} \mathrm{ha}^{-1}\right)$} \\
\hline & \multicolumn{2}{|c|}{ Grain } & \multicolumn{2}{|c|}{ Straw } & \multicolumn{2}{|c|}{ Grain } & \multicolumn{2}{|c|}{ Straw } \\
\hline \multicolumn{9}{|c|}{ Nitrogen levels $\left(\mathrm{kg} \mathrm{ha}^{-1}\right)$} \\
\hline $120\left(\mathrm{~N}_{1}\right)$ & 81.55 & 82.55 & 44.77 & 45.52 & 195.57 & 198.89 & 345.13 & 351.11 \\
\hline $150\left(\mathrm{~N}_{2}\right)$ & 79.24 & 80.46 & 43.60 & 44.19 & 188.77 & 191.35 & 335.24 & 339.87 \\
\hline $180\left(\mathrm{~N}_{3}\right)$ & 73.65 & 74.69 & 41.76 & 42.42 & 172.65 & 177.83 & 320.24 & 327.42 \\
\hline SEm \pm & 0.51 & 0.54 & 0.24 & 0.25 & 1.56 & 2.57 & 2.44 & 3.15 \\
\hline $\mathrm{CD}(\mathrm{p} \leq \mathbf{0 . 0 5})$ & 1.49 & 1.60 & 0.71 & 0.73 & 4.58 & 7.54 & 7.18 & 9.24 \\
\hline \multicolumn{9}{|c|}{ Silicon applications (\%) } \\
\hline Control $\left(\mathbf{S i}_{\mathbf{0}}\right)$ & 71.90 & 72.94 & 40.28 & 41.35 & 169.19 & 172.48 & 307.94 & 317.40 \\
\hline $5\left(\mathbf{S i}_{1}\right)$ & 78.29 & 79.51 & 43.78 & 44.28 & 185.00 & 189.68 & 335.70 & 340.38 \\
\hline $10\left(\mathbf{S} \mathbf{i}_{2}\right)$ & 79.94 & 81.09 & 44.23 & 44.78 & 189.74 & 194.48 & 340.50 & 343.65 \\
\hline $15\left(\mathrm{Si}_{3}\right)$ & 82.46 & 83.40 & 45.22 & 45.75 & 198.74 & 203.36 & 349.00 & 354.35 \\
\hline SEm \pm & 0.59 & 0.63 & 0.27 & 0.28 & 1.80 & 2.97 & 2.82 & 3.64 \\
\hline $\mathrm{CD}(\mathrm{p} \leq 0.05)$ & 1.73 & 1.84 & 0.81 & 0.84 & 5.29 & 8.71 & 8.29 & 10.67 \\
\hline
\end{tabular}

For realising economically higher grain yield of rice, $120 \mathrm{~kg} \mathrm{ha}^{-1}$ with $15 \% \mathrm{Si}$ can be recommended as the best treatment combination as it proved to be the best combination that provided optimum dose of nitrogen and silicon for crop growth and yield during both the study years.

\section{References}

Alfoldi, Z., Pinter, L. and Feil, B. 1994. Nitrogen, phosphorus and potassium concentrations in developing maize grains. Journal of Agronomy and Crop Science, 172: 200-206.

Arnold, J.B., Frensch, J. and Taylor, A.R. 2006. 
Influence of inorganic nitrogen and $\mathrm{pH}$ on the elongation of maize seminal roots. Annals of Botany, 97: 867-873.

Dalling, M.J. 1995. The physiological basis of nitrogen redistributing during filling in cereals. P.55-71. In J. E. Harper et al., (ed.) Exploitation of physiological and genetic variability to enhance crop productivity. American Society of Plant Physiologists, Rockville, MD.

DES, 2012-2013. Economic Survey, Directorate of Economics and Statistics. Government of Jammu and Kashmir, Pp. 123, 129-130.

Dobermann, A. and Fairhurst, T. 1997. Field Handbook. Nutritional disorders and nutrient management in rice. International Rice Research Institute (IRRI). Potash and phosphate Institute of Canada (PPIC), pp. 162.

Fageria, N. K., Dos, S. A. B and Cutrim, V. D. A. 2009. Nitrogen uptake and its association with grain yield in lowland Rice genotypes. Journal of Plant Nutrition, 32: 1965-1974.

Fageria, N. K., Slaton, N. A and Baligar, V. C. 2003. Nutrient management for improving lowland rice productivity and sustainability. Advances in Agronomy, 80: 63-152.

Fallah, A. 2000. Effects of silicon and nitrogen on growth, lodging and spikelet filling in Rice (Oryza sativa L.). Ph.D Thesis. UPLB.

FAO. 2014. FAO STAT, Production Statistics, Food and Agriculture Organization.

Jackson, M.L. 1973. Soil chemical analysis. $2^{\text {nd }}$ Median Reprint, Prentices Hall of India. Private Limited., New Delhi, p. 498.

Lawlor, D.W. 2002. Carbon and nitrogen Assimilation in Relation to Yield: Mechanisms are the Key to Understanding Production Systems. Journal of Experimental Botany, 53:773-787.
Liang, Y., Sun, W., Zhu, Y. and Christie, P. 2007. Mechanisms of silicon mediated alleviation of abiotic stress in higher plants. A review Environmental Pollution, 147: 422-428.

Ma, J. F. 2004. Role of silicon in enhancing the resistance of plants to biotic abiotic stresses. Soil Science Plant Nutrition, 50: 11-18.

Mae, T. 1997. Physiological nitrogen efficiency in rice. Nitrogen utilization, photosynthesis and yield potential. Plant and Soil, 196: 201-210.

Mesquita, E. E. and Pinto, J.C. 2000. Nitrogen levels and sowing methods on forage yield produced after harvesting of millet seed (Pennisetum glaucum (L.) R. Br.) [Portuguese]. Revista Brasileira de Zootecnia, 29: 971-977.

Pathan, S.H., Bhilare, R.L. and Damame, S.V. 2010. Seed yield of forage pearl millet varieties as influenced by nitrogen levels under rainfed condition. Journal of Maharashtra Agricultural University, 35:306-308.

Rajamani, K., Gunti, B.R., Vemuri, S. and Bellamkanda, R. 2013. Effect of silicon and nitrogen nutrition on pest and disease intensity in rice. Journal of Agricultural Science and Technology, 3: 568-574.

Shinano, T., Osaki, M. and Tadano. T. 1995. Comparison of growth efficiency between rice and soybean at the vegetative growth stage. Soil Science Plant Nutrition. 41: 471- 480 .

Singh, R. K., Ahuja, U. and Ahuja, S. C. 2006. Basmati for prosperity. Indian Farming, 56: 33-36.

\section{How to cite this article:}

Rukhsana Jan, Farooq Ahmad Aga, Monica Reshi and Khalid Ul Islam Rather. 2020. Impact of Nitrogen and Silicon on Growth Parameters and Nutrient Uptake of Transplanted Rice (Oryza sativa L.) under Temperate Conditions. Int.J.Curr.Microbiol.App.Sci. 9(04): 2189-2195. doi: https://doi.org/10.20546/ijcmas.2020.904.262 